\begin{tabular}{|c|c|c|}
\hline $\begin{array}{l}\text { Editorial \& Publishing Offices : } \\
\text { Macmillan \& Co., LTD. } \\
\text { St. MARTIN’s STREET } \\
\text { LoNDON, W.C.2 }\end{array}$ & & $\begin{array}{l}\text { Telegraphic Address: } \\
\text { PHusis, LESQdaRE, LoNDON } \\
\text { Telephone Number : } \\
\text { WHITEHALL 883I }\end{array}$ \\
\hline Vol. I4I & SATURDAY, APRIL r6, 1938 & No. 3572 \\
\hline
\end{tabular}

\title{
The Protectorates and the Union in South Africa
}

$\mathrm{N}^{\mathrm{A}}$ ATIVE affairs in the greater part of South Africa, though no longer under the jurisdiction of the British Parliament, continue to be a prominent factor in the relations between Great Britain and the Union. Both inside the British Parliament and without, there is a spirit of watchfulness, which gives close regard not only to any action of the Union Government, but also to the currents of public opinion in South Africa in all matters affecting the present welfare and future development of the native and coloured popula. tions. In questions relating to the inhabitants of the Protectorates and Territories under British administration, in which this body of informed opinion can make its influence effective, its aim is to avoid opening the door to either exploitation or treatment considered detrimental or not in accord with the methods and principles of native administration in the territories, when the inhabitants of these territories cross the Union borders to meet the demand for labour. Hence it is usual for the appearance of the Protectorates on the question paper of the House of Commons to herald a lively and instructive debate.

An important statement in response to questions dealing with the future of the Protectorates was made by Mr. Malcolm MacDonald, H.M. Secretary of State for Dominion Affairs, in the House of Commons on March 29. It contained an explicit reaffirmation of policy, and went on to announce two practical measures, which are to be put into operation forthwith. In the matter of policy, Mr. MacDonald, while recognizing on behalf of the British Government the meaning and intention of the sections of the South Africa Act of 1909 which deal with transfer, also emphasized the binding character of the pledges that transfer to the Union Government would not take place until, on one hand, the wishes of the natives had been most carefully considered, and on the other, the United Kingdom Parliament had been given the fullest opportunity to express its views. In the meantime, he went on to say, a conference is to be appointed consisting of three representatives of the Union Government and the three resident commissioners of the Protectorates. This conference is to study "openings for co-operation between the Union Government and the Administrations in matters affecting the development of the territories, and to consider any matters of joint concern to the Union and the territories". As regards the nature of the inquiries, it was indicated in subsequent debate that they are to be of a technical character, such as the prevention and control of animal diseases, marketing of produce, prevention of bubonic plague, etc.

The second measure is the preparation by the Union Government of a series of memoranda, which as a whole will place before the peoples of the Territories, native and other, a clear picture of the terms on which the transfer of the government should take place. These terms, it was said, would follow closely the provisions of the schedule of the South Africa Act and deal with the conditions of government, the maintenance of tribal institutions, the economic advantages to accrue to the territories and so forth.

Taken at their face value, these two practical measures have much to commend them. In bringing them forward, the British Government has been anxious to further the policy of cooperation adopted three years ago, of which the aim, as stated at the time, was to demonstrate to the peoples of the territories that "the Union 
Government are working in concert with the local administrations with a real and generous desire to develop and improve conditions in the territories". The Union Government in dealing with the Protectorates under this arrangement has been as generous in giving financial and other assistance as it has been to South-West Africa; and its attitude merits recognition. The conference which is to be set up should help to alleviate the legitimate grievances of the Union-advanced as one of the reasons for transfer, and indeed one of the strongest-in that the natives of the territories, who are economically dependent upon the Union, are beyond its control in matters in which the welfare of the Union is vitally affected, such as, for example, the control and prevention of cattle and other diseases, labour supply and other technical or difficult questions of a like character.

There was evident anxiety felt in the House of Commons lest the convention should not be sufficiently possessed of the necessary expert knowledge of such subjects, while there was also perturbation because of the fact that the natives are not to be represented. On both counts Mr. MacDonald expressed confidence in the knowledge of the resident commissioners, as well as in their sense of responsibility for the interests of the natives of their respective territories.

Later in the debate, it became abundantly clear that the members of the House also felt considerable apprehension lest acceptance in principle of the preparation of the memoranda-apparently their preparation is already well advanced-should be construed as a pledge of transfer. This elicited the assurance that the memoranda were no more than an intimation of how the Union Government would propose to deal with the matters recited in the schedule of the Act of 1909, and further that they would be issued in a readily accessible form.

At this point it may be regarded as appropriate and, indeed, instructive, to refer to a statement of future native policy which indicates the line of approach of a legislature outside the Union. In laying the foundation stone of the David Livingstone memorial mission school at Ntabasinduna, Mr. Huggins, the Prime Minister of Southern Rhodesia, announced that in the coming year the Government will provide additional advanced training for natives in training schools. At the same time, he foreshadowed a policy of segregation in which the country would be divided up into separate 'white' and 'black' areas. In the black areas the native is to be protected from white competition. In the white areas the native will be allowed to assist, but not to compete with the white man. Native education, he went on to say, would be by missions and not by the State, until natives had a background of Christianity.

Criticism of such a scheme is obviously out of place, until it is possible to see how far the native tribal controls, to which Mr. Huggins referred, are to be retained. It seems illogical to deprecate the effect of white man's law, religion and example, and yet to refuse the facilities for advanced education until a background of Christianity has been acquired.

In fact the trend of anthropological investigation, that is, investigation not only of native thought and institutions in their integrity, but also as they are affected by European culture contacts, now seems to suggest that if tribal controls are to be regarded as of value, and utilized in the moral training of the individual, early education will involve a scientific and objective study of native taboos and institutions. This cannot fairly be asked of a mission, to which education is left without State assistance or control.

If the Union Government, apart from the spur of advantages to accrue to the Union, is urgent for early transfer of the Protectorates out of a desire to help them, the preparation of the memoranda affords an opportunity for approach to the solution of the problem of native development such as has never occurred before in South Africa, free from tradition and prejudice and the preponderating claims for consideration of a white population. It should then be possible by a scientific and dispassionate study of the situation as a whole, to work out a scheme of administration, education and training, not overlooking opportunities for utilizing that training in after-life which would make the disintegration of tribal life, inevitable in the long run, a slow and gradual process, in which a sense of individuality, appropriately and advantageously suppressed in a tribal form of existence, could be built up to fit the native to take his place in a more advanced civilization. It may be recalled that to carry out an ambitious scheme of this nature South Africa has at its service a school of anthropologists, not only well versed in the study of African tribal thought and institutions, but also well trained, as it has already shown by its work, to gauge the trend and effect of cultural modification and contacts among African peoples. 